\title{
Expanding the clinical spectrum of the mitochondrial mutation A13084T in the ND5 gene
}

Roberta Brusa, MD,* Eleonora Mauri, MD,* Laura Dell'Arti, MD, Francesca Magri, MD, Dario Ronchi, MD, PhD, Valeria Minorini, MD, Claudia Mainetti, MD, Delia Gagliardi, MD, Irene Faravelli, MD, Megi Meneri, MD, PhD, Nereo Bresolin, MD, Francesco Viola, MD, Stefania Corti, MD, PhD, and Giacomo Pietro Comi, MD
Correspondence

Dr. Comi

giacomo.comi@unimi.it

Neurol Genet 2020;6:e511. doi:10.1212/NXG.0000000000000511

Our group previously published about a patient with a LS/MELAS (Leigh syndrome/ mitochondrial myopathy, encephalopathy, lactic acidosis, and stroke-like episodes) overlap phenotype associated with a novel mitochondrial mutation in the ND5 gene. ${ }^{1}$ At that time, his 38year-old mother presented only migraine and asymptomatic bilateral optic atrophy, without other neurologic signs or symptoms. Headache attacks, occurring about twice a month, were localized mainly in the right frontoparietal region, sometimes associated with nausea or vomit or phonophotophobia, and were responsive to nonsteroidal anti-inflammatory drugs. She carried lower levels of heteroplasmy of the same A13084T mutation (57\% in lymphocytes and 48\% in fibroblasts) compared with her son ( $82 \%$ in blood and $72 \%$ in fibroblasts).

At 53 years of age, she was admitted to our hospital to treat the recent worsening of migraine attacks in terms of frequency (up to 12 a month) and severity. Neurologic examination was unremarkable, including manual visual field by confrontation. Ophthalmologic examination revealed visual acuity loss, which onset was not exactly datable. Visual acuity was 20/32 in the right eye (oculus dexter [OD]) and 20/40 in the left eye (oculus sinister [OS]). Fundoscopy confirmed known bilateral optic disc pallor and excavation, with major involvement of the temporal sectors (figure, A). Intraocular pressure was $16 \mathrm{~mm} \mathrm{Hg}$ bilaterally. Computerized visual field analysis showed a moderate-severe defect in the superotemporal sector in the OD and centrocecal scotoma in the OS (figure, B). No retinal abnormalities were detected at infrared and autofluorescence retinoscopy (figure, C), whereas optical coherence tomography showed a diffused macular ganglion cell layer thinning and a retinal nerve fiber layer atrophy of the temporal sectors bilaterally (figure, D). Visual evoked response to flash stimulation was reduced in amplitude in the OS, with a markedly increased latency, and normal in the OD. Serum lactate was slightly elevated $(1.6 \mathrm{mmol} / \mathrm{L}$; normal values $<1.3 \mathrm{mmol} / \mathrm{mol})$, and folate levels were mildly reduced $(3.5 \mu \mathrm{g} / \mathrm{L}$; normal range $4.6-18.7 \mu \mathrm{g} / \mathrm{L})$. The remaining blood tests, including thyroid and liver functions, were otherwise normal. We performed a brain MRI with gadolinium that also included studies of orbits and cerebral vessels. Subcortical white matter carried nonspecific hyperintensities in T2 sequences, but no signs of previous stroke-like lesions were detected. No optic nerve or chiasm abnormalities were seen on scans. Arteries of the circle of Willis were normally represented.

Our findings pointed out to a phenotype similar to Leber hereditary optic neuropathy (LHON), not previously diagnosed because the patient did not perform further evaluations in the past years nor reported ocular symptoms so far. Idebenone (dosage $90 \mathrm{mg}$ trice a day) was added to the treatment with coenzyme Q10 (dosage $50 \mathrm{mg}$ twice a day). ${ }^{2}$ Because LHON

\footnotetext{
*These authors equally contributed to the article.
}

From the Neurology Unit (R.B., E.M., F.M., D.R., M.M., N.B., S.C.); Ophthalmological Unit (L.D.A., V.M., C.M., F.V.), IRCCS Foundation Ca' Granda Ospedale Maggiore Policlinico; Department of Pathophysiology and Transplantation (D.R., D.G., I.F., N.B., S.C., G.P.C.), Dino Ferrari Center, University of Milan; and Neuromuscular and Rare Diseases Unit (G.P.C.), IRCCS Foundation Ca' Granda Ospedale Maggiore Policlinico, Milan, Italy.

The Article Processing charge was funded by authors.

Go to Neurology.org/NG for full disclosures. Funding information is provided at the end of the article.

This is an open access article distributed under the terms of the Creative Commons Attribution-NonCommercial-NoDerivatives License 4.0 (CC BY-NC-ND), which permits downloading and sharing the work provided it is properly cited. The work cannot be changed in any way or used commercially without permission from the journal. 


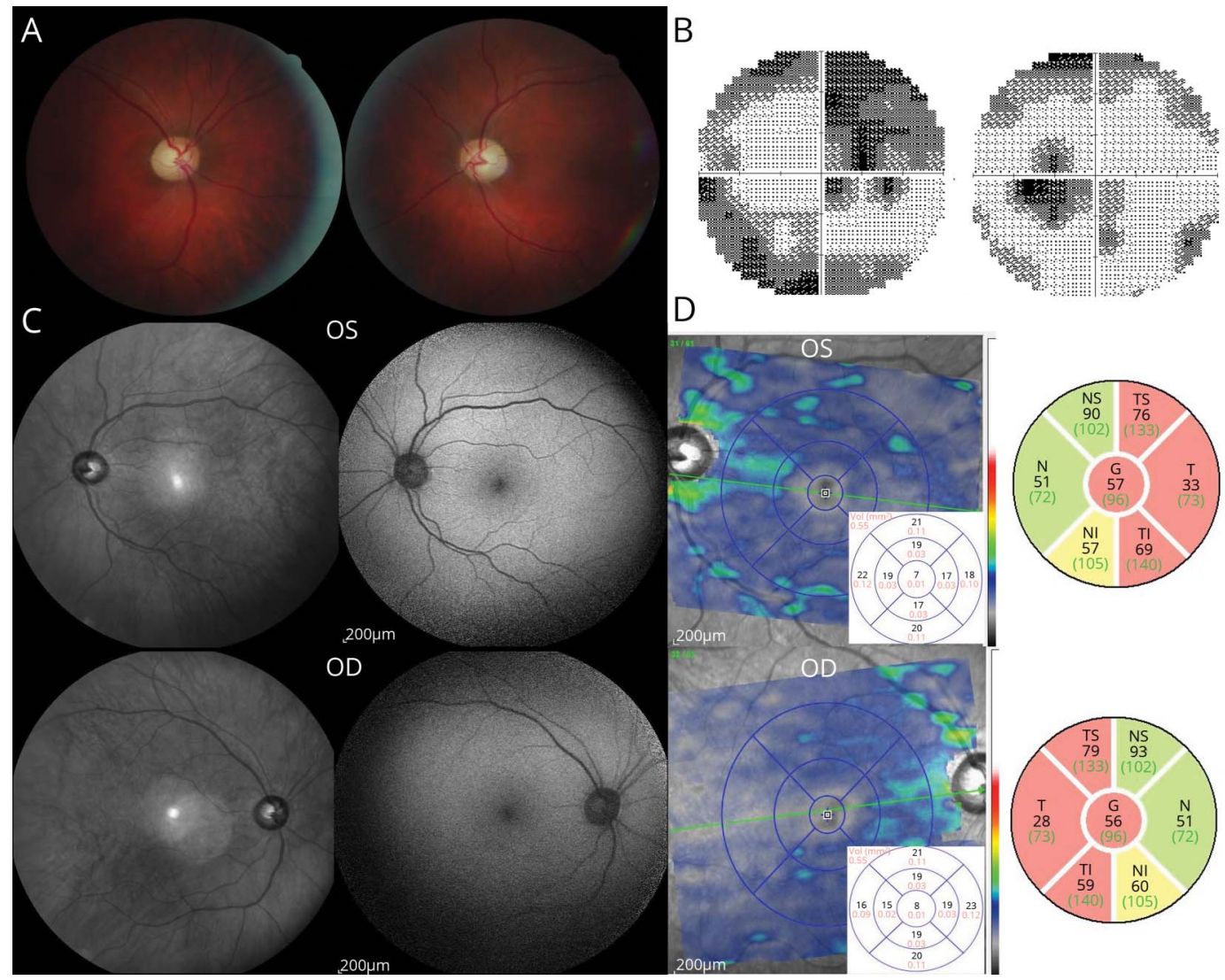

Fundus color image showing bilateral optic disc pallor and excavation, with main involvement of the temporal sectors (A). Humphrey automatic visual field analysis 30-2 revealing a superotemporal defect in the OD and centrocecal scotoma in the OS (B). No retinal abnormalities were detected at IR and autofluorescence (C, OS upper row, OD lower row), whereas OCT showed a diffused macular ganglion cell layer thinning and a RNFL atrophy of the temporal sectors ( $D$, OS upper row, OD lower row). IR = infrared retinoscopy; OCT = optical coherence tomography; OD = oculus dexter; OS = oculus sinister; RNFL = retinal nerve fiber layer.

may be associated with arrhythmias and mitochondriopathies with cardiac involvement, we performed ECG, echocardiogram, and 24-hour ECG monitoring, resulted all normal. Frequency of headache episodes responded partially to riboflavin $200 \mathrm{mg}$ twice a day. ${ }^{3}$ Clinical evaluation and ophthalmologic assessments, performed 1 year later, were substantially stable.

Here, we describe the mitochondrial A13084T mutation in the NDS gene, still not reported in other families, in association with a LHON-like presentation and migraine, in addition to the previously described LS/MELAS phenotype. ${ }^{1}$ ND5 is a mtDNA gene encoding for the nicotinamide adenine dinucleotide dehydrogenase 5, part of the complex I of the respiratory chain in mitochondria, which mutations have been so far associated with MELAS, LHON, Leigh syndrome (LS), and overlap syndromes (MELAS/LS, MELAS/LHON/LS, MELAS/Chronic Progressive External Ophthalmoplegia, MELAS/Myoclonic Epilepsy with Ragged-Red Fibers). ${ }^{4,5}$

LHON, usually affecting young men, is typically characterized by bilateral and painless loss of vision, with centrocecal scotoma, prominent temporal optic nerve atrophy, and selective degeneration of retinal ganglion cells, ${ }^{2}$ as occurred in our patient. However, our patient did not complain of acute or subacute visual loss. In the literature, heteroplasmy has been reported in $10 \%-15 \%$ of LHON cases with levels above $70 \%$, ${ }^{6}$ which are higher compared with those found in our patient. We speculate that lower heteroplasmy levels and female sex may be responsible for the milder presentation of visual loss in our patient, although further observation is needed to confirm this theory.

Despite being a common disorder in the population, a higher prevalence of migraine has been reported in several mitochondrial disorders, probably because of impaired oxidative metabolism in the CNS. ${ }^{7}$

In conclusion, our findings expand the spectrum of phenotypes arising from the A13084T mutation. We support the role of NDS as a candidate gene for LHON or LHON-like presentations. Moreover, we suggest periodic evaluations in paucisymptomatic or asymptomatic carriers to detect subclinical signs of optic atrophy. 


\section{Acknowledgments}

The authors gratefully thank the Associazione Centro Dino Ferrari for its support.

\section{Study funding}

The project received partial support from the Italian Ministry of Health to G.P. Comi.

\section{Disclosure}

All the authors reported no disclosures. Go to Neurology.org/ NG for full disclosures.

\section{Publication history}

Received by Neurology: Genetics May 1, 2020. Accepted in final form June 11, 2020.

Appendix Authors

\begin{tabular}{|c|c|c|}
\hline Name & Location & Contribution \\
\hline $\begin{array}{l}\text { Roberta } \\
\text { Brusa, MD }\end{array}$ & $\begin{array}{l}\text { IRCCS Foundation Ca' } \\
\text { Granda Ospedale Maggiore } \\
\text { Policlinico, Milan, Italy }\end{array}$ & $\begin{array}{l}\text { Conceptualized and } \\
\text { wrote the manuscript; } \\
\text { performed the neurologic } \\
\text { evaluations of the patient; } \\
\text { and collected clinical history } \\
\text { and other assessments }\end{array}$ \\
\hline $\begin{array}{l}\text { Eleonora } \\
\text { Mauri, MD }\end{array}$ & $\begin{array}{l}\text { IRCCS Foundation Ca' } \\
\text { Granda Ospedale Maggiore } \\
\text { Policlinico, Milan, Italy }\end{array}$ & $\begin{array}{l}\text { Conceptualized and } \\
\text { wrote the manuscript; } \\
\text { performed the neurologic } \\
\text { evaluations of the patient; } \\
\text { and collected clinical } \\
\text { history and other } \\
\text { assessments }\end{array}$ \\
\hline $\begin{array}{l}\text { Laura } \\
\text { Dell'Arti, } \\
\text { MD }\end{array}$ & $\begin{array}{l}\text { IRCCS Foundation Ca' } \\
\text { Granda Ospedale Maggiore } \\
\text { Policlinico, Milan, Italy }\end{array}$ & $\begin{array}{l}\text { Wrote the manuscript; } \\
\text { assembled the figure; and } \\
\text { performed ophthalmologic } \\
\text { evaluations }\end{array}$ \\
\hline $\begin{array}{l}\text { Francesca } \\
\text { Magri, MD }\end{array}$ & $\begin{array}{l}\text { IRCCS Foundation Ca' } \\
\text { Granda Ospedale Maggiore } \\
\text { Policlinico, Milan, Italy }\end{array}$ & Reviewed the manuscript \\
\hline $\begin{array}{l}\text { Dario } \\
\text { Ronchi, } \\
\text { MD, PhD }\end{array}$ & $\begin{array}{l}\text { IRCCS Foundation Ca' } \\
\text { Granda Ospedale Maggiore } \\
\text { Policlinico, Milan, Italy }\end{array}$ & Performed mtDNA studies \\
\hline $\begin{array}{l}\text { Valeria } \\
\text { Minorini, } \\
\text { MD }\end{array}$ & $\begin{array}{l}\text { IRCCS Foundation Ca' } \\
\text { Granda Ospedale Maggiore } \\
\text { Policlinico, Milan, Italy }\end{array}$ & $\begin{array}{l}\text { Performed orthoptic } \\
\text { evaluations }\end{array}$ \\
\hline
\end{tabular}

Appendix (continued)

\begin{tabular}{|c|c|c|}
\hline Name & Location & Contribution \\
\hline $\begin{array}{l}\text { Claudia } \\
\text { Mainetti, } \\
\text { MD }\end{array}$ & $\begin{array}{l}\text { IRCCS Foundation Ca' } \\
\text { Granda Ospedale Maggiore } \\
\text { Policlinico, Milan, Italy }\end{array}$ & $\begin{array}{l}\text { Performed orthoptic } \\
\text { evaluations }\end{array}$ \\
\hline $\begin{array}{l}\text { Delia } \\
\text { Gagliardi, } \\
\text { MD }\end{array}$ & $\begin{array}{l}\text { IRCCS Foundation Ca' } \\
\text { Granda Ospedale Maggiore } \\
\text { Policlinico, University of } \\
\text { Milan, Italy }\end{array}$ & $\begin{array}{l}\text { Participated in neurologic } \\
\text { evaluations of the patient }\end{array}$ \\
\hline $\begin{array}{l}\text { Irene } \\
\text { Faravelli, } \\
\text { MD }\end{array}$ & $\begin{array}{l}\text { IRCCS Foundation Ca' } \\
\text { Granda Ospedale Maggiore } \\
\text { Policlinico, University of } \\
\text { Milan, Italy }\end{array}$ & $\begin{array}{l}\text { Reviewed the manuscript } \\
\text { and participated in } \\
\text { neurologic evaluations }\end{array}$ \\
\hline $\begin{array}{l}\text { Megi } \\
\text { Meneri, } \\
\text { MD, PhD }\end{array}$ & $\begin{array}{l}\text { IRCCS Foundation Ca' } \\
\text { Granda Ospedale Maggiore } \\
\text { Policlinico, Milan, Italy }\end{array}$ & $\begin{array}{l}\text { Participated in early } \\
\text { neurologic evaluations }\end{array}$ \\
\hline $\begin{array}{l}\text { Nereo } \\
\text { Bresolin, } \\
\text { MD }\end{array}$ & $\begin{array}{l}\text { IRCCS Foundation Ca' } \\
\text { Granda Ospedale Maggiore } \\
\text { Policlinico, Milan, Italy }\end{array}$ & Reviewed the manuscript \\
\hline $\begin{array}{l}\text { Francesco } \\
\text { Viola, MD }\end{array}$ & $\begin{array}{l}\text { IRCCS Foundation Ca' } \\
\text { Granda Ospedale Maggiore } \\
\text { Policlinico, Milan, Italy }\end{array}$ & Reviewed the manuscript \\
\hline $\begin{array}{l}\text { Stefania } \\
\text { Corti, MD, } \\
\text { PhD }\end{array}$ & $\begin{array}{l}\text { IRCCS Foundation Ca' } \\
\text { Granda Ospedale Maggiore } \\
\text { Policlinico, University of } \\
\text { Milan, Italy }\end{array}$ & Reviewed the manuscript \\
\hline $\begin{array}{l}\text { Giacomo } \\
\text { Comi, MD }\end{array}$ & $\begin{array}{l}\text { IRCCS Foundation Ca' } \\
\text { Granda Ospedale Maggiore } \\
\text { Policlinico, University of } \\
\text { Milan, Italy }\end{array}$ & $\begin{array}{l}\text { Contributed for intellectual } \\
\text { content and reviewed the } \\
\text { manuscript }\end{array}$ \\
\hline
\end{tabular}

\section{References}

1. Crimi M, Galbiati S, Moroni I, et al. A missense mutation in the mitochondrial ND5 gene associated with a Leigh-MELAS overlap syndrome. Neurology 2003;60:1857-1861.

2. Carelli V, Carbonelli M, de Coo IF, et al. International Consensus Statement on the Clinical and Therapeutic Management of Leber hereditary optic neuropathy. J Neuroophthalmol 2017;37:371-381.

3. High-dose riboflavin treatment is efficacious in migraine prophylaxis: an open study in a tertiary care centre. PubMed - NCBI [online]. Available at: www.ncbi.nlm.nih.gov/ pubmed/15257686. Accessed March 18, 2019.

4. Ng YS, Lax NZ, Maddison P, et al. MT-ND5 mutation exhibits highly variable neurological manifestations at Low mutant Load. EBioMedicine 2018;30:86-93.

5. Seong MW, Choi J, Park SS, Kim JY, Hwang J-M. Novel MT-ND5 gene mutation identified in Leber's hereditary optic neuropathy patient using mitochondrial genome sequencing. J Neurol Sci 2017;375:301-303.

6. Chinnery PF, Andrews RM, Turnbull DM, Howell NN. Leber hereditary optic neuropathy: does heteroplasmy influence the inheritance and expression of the G11778A mitochondrial DNA mutation? Am J Med Genet 2001;98:235-243.

7. Vollono C, Primiano G, Della Marca G, Losurdo A, Servidei S. Migraine in mitochondrial disorders: prevalence and characteristics. Cephalalgia 2018;38:1093-1106. 


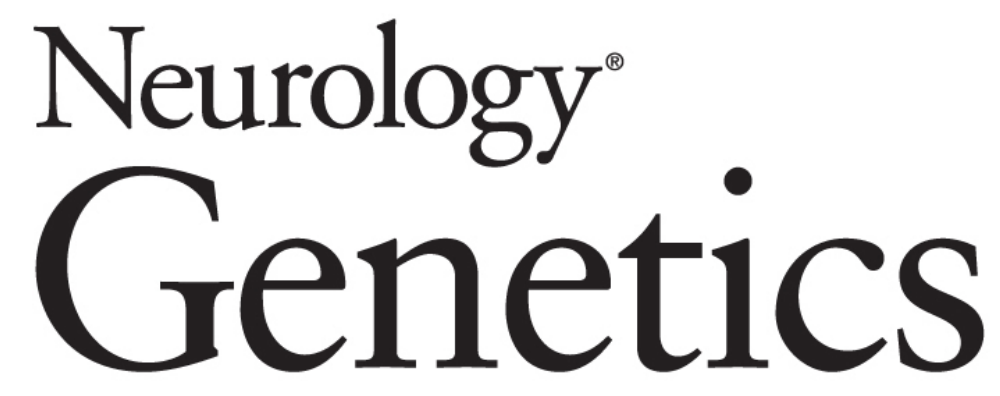

Expanding the clinical spectrum of the mitochondrial mutation A13084T in the ND5
gene

Roberta Brusa, Eleonora Mauri, Laura Dell'Arti, et al.

Neurol Genet 2020;6;

DOI 10.1212/NXG.0000000000000511

This information is current as of September 15, 2020

\section{Updated Information \&} Services

References

Subspecialty Collections

Permissions \& Licensing

Reprints including high resolution figures, can be found at: http://ng.neurology.org/content/6/5/e511.full.html

This article cites 6 articles, 0 of which you can access for free at: http://ng.neurology.org/content/6/5/e511.full.html\#\#ref-list-1

This article, along with others on similar topics, appears in the following collection(s):

\section{Mitochondrial disorders}

http://ng.neurology.org//cgi/collection/mitochondrial_disorders Optic nerve

http://ng.neurology.org//cgi/collection/optic_nerve

Visual loss

http://ng.neurology.org//cgi/collection/visual_loss

Information about reproducing this article in parts (figures,tables) or in its entirety can be found online at:

http://ng.neurology.org/misc/about.xhtml\#permissions

Information about ordering reprints can be found online:

http://ng.neurology.org/misc/addir.xhtml\#reprintsus

Neurol Genet is an official journal of the American Academy of Neurology. Published since April 2015, it is an open-access, online-only, continuous publication journal. Copyright Copyright (C) 2020 The Author(s). Published by Wolters Kluwer Health, Inc. on behalf of the American Academy of Neurology.. All rights reserved. Online ISSN: 2376-7839.

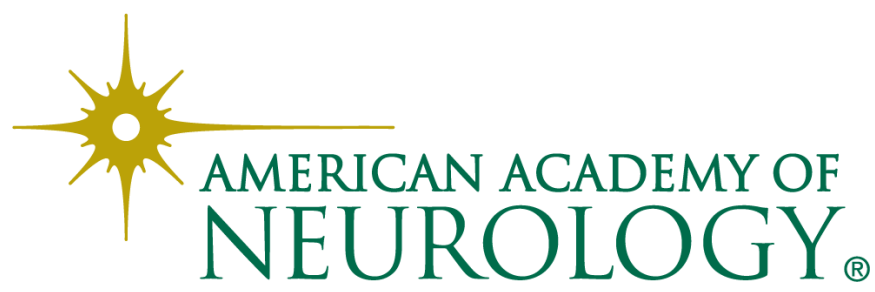

